\title{
Determinants of Adoption of Agricultural Extension Services in the Centre Region of Cameroon
}

\author{
Corine Sorelle Tchapgang Ngomi ${ }^{1}$, Jianzhou Yang ${ }^{1, *}$, Yi Chen ${ }^{1}$ \\ ${ }^{1}$ Economics College of Fujian Agriculture and Forestry University, Fuzhou, Fujian, China \\ ${ }^{*}$ Corresponding author
}

Keywords: Adoption; Agricultural Extension Service; Determinants; Logistic Regression.

\begin{abstract}
This empirical study aimed at assessing the determinants of adoption of agricultural extension services in the centre region of Cameroon using a logistic regression model. Data was collected from 251 farmers categorized as adopters and non-adopters using a structured pretested questionnaire. Results showed that years of education, farm size, income, distance to nearest market and agricultural experience were the most significant determinants of adoption of agricultural extension service in centre region of Cameroon. It is strongly advised that more emphasis be placed on the education of rural farmers by competent authorities or decision makers to ensure wide spread dissemination of this service so as to boost farmers productivity.
\end{abstract}

\section{Introduction}

Agriculture is the spine of most developing economies in the world plays and it plays an important role in food security, living standards improvements, rural development and poverty reduction [1]. Cameroon's agriculture represents about 21.7 percent of Gross Domestic Product (GDP) and absorbs about 60 percent of the active population [2]. Based on the World Bank's article, close to 90 percent of the rural population is engaged in agriculture with one third of them earning their livings from export crops. Given the world's food demand (and particularly Cameroon) there is the need to increase agricultural production. Increasing agricultural production will contribute enormously in reducing poverty (given that more than 55 percent of the rural households are poor), sustaining growth and achieving food security [3]. Agricultural extension remains one of the most important routes to agricultural productivity growth especially in developing countries. It is provided by public institutions, private organisations, NGOs just to mention a few. About $90 \%$ of the world's extension personnel are located in developing countries [4]

In the case of Cameroon, the training of farmers and the dissemination of improved agricultural technology is done through the provision of agricultural extension services in the form of various programmes and or projects implemented by the ministry of agriculture and rural development (MINADER). Some of these projects and or programmes were either dissolved, renewed or new ones created. ACEFA (The Programme for the Improvement of Competitiveness of Family Agropastoral Farms) now PCP-ACEFA (The Programme for the Consolidation and Sustainability of Agropastoral Counselling) jointly coordinated by MINADER and French Development Agency/ (AFD) is the only left programme currently assisting farmers by providing agricultural extension 
services. Despite the consistent promotion by the government and some organisations of the use of modern agricultural input technology in boosting agricultural yields, adoption still remains a challenge therefore resulting in slow productivity.

Very few studies have assessed agricultural extension service in Cameron [such as 5, 6]. [5], examined the services support package of the ACEFA program and its impacts on Family Agropastoral Farms (EFA) and Producer Groups in the Southern Region of Cameroon using percentages. There is no main empirical study on the determinants of adoption of agricultural extension service in Cameroon. Thus having an understanding of the determinants of adoption will be beneficial in designing relevant support systems that will promote sustainable agriculture necessary to improve agricultural productivity and household food security [7].

\section{Literature review}

The adoption theory is based on Everett Rogers' theory of innovation diffusion. These theories rely on the assumption that the purpose of disseminating information is mainly for adoption [8]. Adoption which when plotted over time has a normal bell shaped curve and an s-shaped curve if the cumulative number of adopters are plotted is defined as a decision to fully make use of innovation as the best course of action obtainable. [9, 10], identified farm size, human capital, credit constraint, tenure and labour activity as important determinants of adoption level. Thus a clear understanding of the influence of these factors on adoption is essential in developing strategies [7]. Various factors have been identified as factors influencing the adoption of agricultural extension services by farmers. [11], identified the determinants of adoption of technologies as social, economic and physical factors. In-spite of the fact that determinants can be grouped under different categories, there still is no clear distinguishing feature between variables in each category [1].

Education is one of the most commonly identified demographic factor determining adoption. Most of these studies showed that farmers who had gone to school were more open or willing to adopt new agricultural practices [12, 13, and 14]. Farm size, cost of hired labour, off farm income, human capital (education), labour availability were identified as some of the most important socio economic factors determining the adoption of new agricultural practices [12,10,1]. However, [12] found a positive and insignificant influence of off farm income on the adoption of improved maize varieties.

Moreover, social group belongingness and information acquisition, market distance and credit access have been identified as institutional determinants [15, 10]. [14], identified credit availability as a significant determinant of adoption (that is, the availability of credit increases the chances of the farmers to adopt new technologies).

Most of these studies focused on the determinants of adoption of agricultural technology but no study assessed the determinants of adoption of extension services in Cameroon. Thus our study aim is to fill this gap as agricultural extension service is extending it horizons and on the development agenda of Cameroon as a means of boosting agricultural productivity and welfare.

Hypotheses

$\boldsymbol{H}_{\mathbf{1}_{\mathbf{1}}}$ : Demographic, Socio-economic, Institutional and farm characteristics determine adoption of agricultural extension service in Cameroon.

\section{Methodology}

\subsection{Empirical model}

The decision to adopt or not to adopt agricultural extension service follows a discrete choice model. A binary response model more precisely a binary logistic regression model was used to 
identify and assess the determinants of adoption of agricultural extension service among the rural farmers. The logistic regression model is used because of its simplicity and flexibility of calculation and its probability lies between 0 and 1 [16]. The logit model is based on the logistic cumulative distribution function and depicts a non-linear relationship between the probability of an event occurring and the explanatory variable [17]. Farmers selected mostly grew food crops and those that only concentrated on the production of cash crops were excluded because these crops are mainly produced for sale and not household or immediate consumption.

Table 1. Variables used, description and expected outcome

\begin{tabular}{|c|c|c|c|}
\hline Variable & Type & Description & $\begin{array}{l}\text { Expected } \\
\text { outcome }\end{array}$ \\
\hline Adopt & Dummy & $\begin{array}{l}1 \text { if the farmer adopted agricultural extension } \\
\text { service and } 0 \text { otherwise }\end{array}$ & $\begin{array}{l}\text { Dependent } \\
\text { variable }\end{array}$ \\
\hline Years edu & Continuous & Total number of years of education & + \\
\hline Farm size & Continuous & Total farm size of the farmer in hectares & + \\
\hline Income & Continuous & Farmer's monthly income in FCFA & - \\
\hline Gender & Dummy & Whether the farmer is a male $=1$ or female $=0$ & $+/-$ \\
\hline Age & Continuous & Age of the farmer in years & + \\
\hline Dist. $m k t$ & Continuous & Distance to the nearest market in kilometres & + \\
\hline $\begin{array}{l}\text { Agric. } \\
\exp \end{array}$ & Dummy & Number of years of experience in farming & + \\
\hline $\begin{array}{l}\text { Credit } \\
\text { access }\end{array}$ & Dummy & $\begin{array}{l}\text { Whether the farmer has access to credit for } \\
\text { agriculture. } \mathrm{Yes}=1, \mathrm{No}_{0}=0\end{array}$ & - \\
\hline Tenure & Dummy & Whether the farmer owns land. $\mathrm{Yes}=1, \mathrm{No}=0$ & - \\
\hline Media & Dummy & 1 If the farmer has access to media and 0 if not & + \\
\hline
\end{tabular}

According to [18] the population logit model of the binary dependent variable $\mathrm{Y}$ with multiple explanatory variables is given as

$$
\begin{aligned}
\operatorname{Pr}\left(Y=1 \mid X_{1}, X_{2}, \ldots, X_{k}\right)=F\left(\beta_{0}\right. & \left.+\beta_{1} X_{1}+\beta_{2} X_{2}+\cdots+\beta_{k} X_{k}\right) \\
= & \frac{1}{1+e^{-\left(\beta_{0}+\beta_{1} X_{1}+\beta_{2} X_{2}+\cdots+\beta_{k} X_{k}\right)}}
\end{aligned}
$$

Where,

$\boldsymbol{P r}(\boldsymbol{Y}=\mathbf{1})=$ the probability the farmer adopted agricultural extension service

$\boldsymbol{F}=$ standard logistic regression function

$\boldsymbol{e}=$ exponential function or base of natural logarithm

$\boldsymbol{\beta}_{\mathbf{0}}=$ constant term and $\boldsymbol{\beta}^{\prime} \boldsymbol{s}=$ coefficients

$\boldsymbol{X} \boldsymbol{s}=$ explanatory variables determining the adoption of agricultural extension service

The maximum likelihood method in $\mathrm{R}$ software is used to estimate the coefficients of the logit model. Thus the empirical model of our study is given as; 
Logit (Adopt) $=\beta_{0}+\beta_{1}$ years edu $+\beta_{2}$ farm. size $+\beta_{3}$ income $+\beta_{4}$ gender $+\beta_{5}$ age $+\beta_{6}$ dist. mkt. $+\beta_{7}$ agric. exp. $+\beta_{8}$ credit Access $+\beta_{9}$ tenure $+\beta_{10}$ media $+\mathcal{E}$

From equation two (Eq.2) above, our dependent variable Adopt is a farmer being an adopter or non-adopter of agricultural extension service which takes the value of one (1) if the farmer adopted extension services and zero (0) otherwise. This is regressed on the independent variables listed above whose choice was oriented by the literature [7]. Table 1 provides a description of our model variables and their expected signs. The Variance Inflation Factor (vif) was used to test multi collinearity among continuous explanatory (independent) variables.

\subsection{Data and Descriptive statistics}

This study's empirical analysis is based on data collected from two divisions in the Centre region of Cameroon (that is the Mbam et Inoubou and Lekie) where agricultural extension service is widely spread. A total of 251 farmers were sampled from nine (9) districts in the two divisions in the month of March 2019. A purposive multi-stage stratified random sampling was used to select the surveyed respondent farmers owing to the fact it is practically difficult to obtain a comprehensive list of all the farmers including detail information on their activities. The sampling unit was the household member undertaking farming activities in the household [7]. At the first stage, the Mbam et Inoubou and the Lekie divisions were purposively selected because agricultural production is widely practiced there, agricultural extension service have been provided and implemented and it is an agro-ecological zone. In stage two, six (6) districts were purposively selected from nine (9) districts in the Mbam et Inoubou division to ensure a representation of this area. These districts were selected based on accessibility, availability of farmers during the study period and farmers' monthly scheduled meeting with the advisors. While, only three (3) districts were covered out of nine (9) in the Lekie division. In stage three (3) from the list obtained, a total of 30 groups of farmers associations were randomly selected from the two divisions due to the size of each association or group of farmers. This list of producers groups known as Groupes d'initiative commune (GIC) was provided by the regional delegate of the ACEFA Programme in respective divisions. Groups of farmers selected from each district were further stratified into adopters and non -adopters of agricultural extension service in stage four.

Table 2. Descriptive Statistics

\begin{tabular}{cccccccc} 
Statistic & $\mathrm{N}$ & Mean & St. Dev. & Min & Pctl(25) & Pctl(75) & Max \\
\hline Adopt & 251 & 0.67 & 0.47 & 0 & 0 & 1 & 1 \\
Years of education & 250 & 8.47 & 4.70 & 0.00 & 6.00 & 11.00 & 21.00 \\
Farm size & 236 & 2.36 & 2.43 & 0.005 & 0.50 & 3.00 & 15.00 \\
Income rank & 248 & 2.17 & 1.65 & 1.00 & 1.00 & 2.00 & 7.00 \\
Gender & 251 & 0.51 & 0.50 & 0 & 0 & 1 & 1 \\
Age & 247 & 49.28 & 12.22 & 22.00 & 40.00 & 59.00 & 82.00 \\
Dis nearest market $(\mathrm{km})$ & 240 & 9.85 & 13.59 & 0.00 & 3.50 & 12.00 & 120.00 \\
Agricultural experience & 250 & 20.01 & 13.02 & 1.00 & 10.00 & 30.00 & 55.00 \\
Credit Access & 250 & 0.10 & 0.30 & 0.00 & 0.00 & 0.00 & 1.00 \\
Tenure & 250 & 0.72 & 0.45 & 0.00 & 0.00 & 1.00 & 1.00 \\
Media & 251 & 0.88 & 0.33 & 0 & 1 & 1 & 1 \\
& & & & & & & \\
\hline
\end{tabular}


Data was obtained both at the household level and plot level with the use of a structured pretested questionnaire constructed based on the literature. This questionnaire was administered by trained enumerators who nevertheless were supervised by the author and consisted of questions pertaining to the demographic, socioeconomic, plot level and institutional characteristics of the farmers. Our survey instrument made use of open ended questions and closed ended questions Focus group discussions were equally conducted with a small group of farmers who have intimate knowledge about the topic under consideration to compliment the data obtained through the field survey. Table 2 gives a summary statistics of the variables used in our regression analysis. It shows that at least 67 percent of farmers adopted extension services and the average number of years spent in formal education by a farmer is 8 years (meaning most farmers have at least primary education) although some farmers never went to school. The average age of the sampled farmers is 49 years with the youngest being 22 years and the oldest farmer 82 years.

\section{Results and Discussion}

Table 3 shows our binary logistic regression results with the corresponding marginal effects which is the change in the outcome resulting from a change in the explanatory variable holding all other variables constant.

Table 3. Logistic Regression Results and Marginal Effect Results

Dependent variable: Adopt

\section{Logit estimates Marginal effects}

(1)

(2)

\begin{tabular}{ccccc} 
Independent variable & Coeff & Std err & Coeff & Std err \\
\hline Constant & -0.8820 & $(1.0426)$ & & \\
Age & 0.0010 & $(0.0164)$ & 0.0002 & $(0.0034)$ \\
Gender & -0.2868 & $(0.3661)$ & -0.0600 & $(0.0765)$ \\
Years of education & $0.0670^{*}$ & $(0.0391)$ & $0.0140^{*}$ & $(0.0081)$ \\
Income rank & $-0.2502^{* *}$ & $(0.1018)$ & $-0.0523^{* *}$ & $(0.0213)$ \\
Farm size & $0.1405^{*}$ & $(0.0809)$ & $0.0294^{*}$ & $(0.0169)$ \\
Dis nearest market (km) & $0.0658^{* * *}$ & $(0.0253)$ & $0.0138^{* * *}(0.0050)$ \\
Media & 0.5709 & $(0.5025)$ & 0.1285 & $(0.1196)$ \\
Tenure & -0.4339 & $(0.3597)$ & -0.0869 & $(0.0685)$ \\
Agricultural experience & $0.0297^{*}$ & $(0.0157)$ & $0.0062^{*}$ & $(0.0033)$ \\
Credit.access & 0.1216 & $(0.6108)$ & 0.0249 & $(0.1221)$ \\
\hline Observations & \multicolumn{5}{c}{219} & & \\
Log Likelihood & -125.6671 & & \\
Akaike Inf. Crit. & 273.3343 & & \\
McFadden pR2 & 5 & 0.2075 & & \\
\hline
\end{tabular}

*Significant at $10 \%$ level, **Significant at $5 \%$ level, ***Significant at $1 \%$ level.

Looking at the demographic characteristics, the variable Years of Education is positive and significantly related to adoption of agricultural extension service by the farmer. The marginal effect results shows that an additional year increase in the education of the farmer, increases the 
probability of adopting extension service by 0.014 . This result is consistent with that of $[12,13,19$, 20 and 21]. However this result contradicts that [15] who found a negative and non-significant relationship between education and access to extension service by rural women in Ghana.

The effect of farm size (a farm characteristic) on adoption is significant at 10 percent and positive showing that farmers with bigger farm sizes tend to adopt agricultural extension services compared to farmers with smaller farm sizes. This result is in line with that of [12, 15 and 19].

Moreover, socioeconomic characteristics such as Income and distance to the nearest market are significant at 5 percent and 1 percent level respectively. Income shows a negative relationship with adoption of agricultural extension service implying that the higher the income of the farmer, the lower the probability of him adopting agricultural extension service. The result obtained is consistent with that of [22]. On the other hand, distance to the nearest market is positively related to adoption of extension service which is consistent with the work of [14]. The marginal effect result shows that if distance from the farmer's farm to the nearest market increases by one kilometre, the probability of the farmer adopting extension service will increase by 0.0122 . This estimated probability is significant at $1 \%$ level. The variable agricultural experience is also found to be significant and positively related to adoption implying that the higher the number of years of farming experience by the farmer, the greater is the probability that the farmer will adopt extension service. Age though not significant has a positive relationship with adoption of agricultural extension service implying that the older the farmer gets, the more inclined he is to adopt extension service probably because as they grow old they realise they can't work as much as before, thus they might adopt agricultural extension service in order to learn new technics of farming which can help them in their daily farming activities. This result is consistent with the findings of [15, 7, and 22] whose results are positive and significant.

Institutional characteristics such as credit access and media shows a non-significant positive effect of credit access by the farmer on adoption implying that the more the farmers have access to credit, the greater is the probability that they adopt agricultural extension service.

\section{Conclusion}

Thus based on our results, more emphasis should be placed on the education and training of rural farmers so that more farmers will be opened to the adoption of new ideas. Given that this study covers only two divisions of centre region of Cameroon, further empirical studies are essential to check whether factors affecting the adoption of agricultural extension service have the same effect in other divisions and regions of Cameroon. Moreover, more rigorous analysis with the use of panel data could be considered in future research to confirm the findings of this study. Due to the growing emphasis laid on agricultural extension in Cameroon, studies assessing the impact of the adoption of these services on farmers' yields and their household food security is a necessity.

\section{References}

[1] Mwangi, M., \& Kariuki, S. (2015). Factors determining adoption of new agricultural technology by smallholder farmers in developing countries. Journal of Economics and sustainable development, $6(5)$.

[2] AGRICOLE, D. L. S. (2014). République du Cameroun.

[3] https://www.worldbank.org/en/news/feature/2013/06/18/in-cameroon-agriculture-is-reemergingas-a-promising-industry

[4] Anderson, J. R. (2008). Agricultural advisory services. 
[5] Fouepe, G. H. F., Watio, M. S., \& Havard, M. (2017). Approaches, Effects and Challenges of Agricultural Advisory Services Experienced by the Program for the Improvement of the Competitiveness of Family Agro-pastoral Farms (ACEFA) in Dja-et-Lobo Division (Cameroon). Asian Journal of Agricultural Extension, Economics \& Sociology, 1-11.

[6] Amungwa, F., \& Baye, F. (2014). Appraisal of the agricultural extension system of family farm schools in Cameroon. Asian Journal of Agricultural Extension, Economics and Sociology, 3(6), 530-543.

[7] Ntshangase, N., Muroyiwa, B., \& Sibanda, M. (2018). Farmers' perceptions and factors influencing the adoption of no-till conservation agriculture by small-scale farmers in Zashuke, KwaZulu-Natal Province. Sustainability, 10(2), 555.

[8] Straub, E. T. (2009). Understanding technology adoption: Theory and future directions for informal learning. Review of educational research, 79(2), 625-649.

[9] Rogers, E. (1962). (1995). Diffusion of innovations. New York: Free Press.

[10] Feder, G., Just, R. E., \& Zilberman, D. (1985). Adoption of agricultural innovations in developing countries: A survey. Economic development and cultural change, 33(2), 255-298.

[11] Lavison, R. K. (2013). Factors influencing the adoption of organic fertilizers in vegetable production in Accra. University of Ghana.

[12] Alene, A. D., Poonyth, D., \& Hassan, R. M. (2000). Determinants of adoption and intensity of use of improved maize varieties in the central highlands of Ethiopia: A tobit analysis. Agrekon, 39(4), 633-643.

[13] Chandio, A. A., \& Yuansheng, J. (2018). Determinants of adoption of improved rice varieties in northern Sindh, Pakistan. Rice Science, 25(2), 103-110.

[14] Muyanga, M. (2009). Smallholder adoption and economic impacts of tissue culture banana in Kenya. African Journal of Biotechnology, 8(23).

[15] Abdallah, A.-H., \& Abdul-Rahaman, A. (2016). determinants of access to agricultural extension services: Evidence from smallholder rural women in Northern Ghana. Asian. J. Agric. Exte. Econ. Socio, 9(3), 1-8.

[16] Gujarati, D. (1995). Basic econometrics McGraw-Hill, Singapore.

[17] Wooldridge, J. M. (2013). Introductory econometrics: a modern approach 5th edition. Mason, OH: South-Western.

[18] Stock, J., \& Watson, M. (2003). Introduction to econometrics. Boston: Addison-Wesley.

[19] Arias, D., Leguía, J. J., \& Sy, A. (2013). Determinants of agricultural extension services: The case of Haiti.

[20] Muatha, I. T., Otieno, D. J., \& Nyikal, R. A. (2016). Factors influencing smallholder farmers' awareness of agricultural extension devolution in Kenya: a binary logit analysis.

[21] Adem, M., Worku, H., Beyene,D.,\& Leta,A.(2014). Household level determinants of agricultural extension program Participation: evidence from sekota, Ethiopia. International J. of Current Research 